\title{
FAMILY LIFE EXPERIENCES IN CARING FOR CHILDREN WITH LEUKEMIA:
}

\section{A LITERATURE REVIEW}

Siti Nurjanah ${ }^{1 *}$, Yurike Septianingrum ${ }^{2}$, Moses Glorino Rumambo Pandin ${ }^{3}$

${ }^{1}$ Doctoral of Nursing, Faculty of Nursing, Universitas Airlangga, Jalan Dr. Ir. H. Soekarno,

Mulyorejo, Kec. Mulyorejo, Surabaya, East Java 60115

${ }^{2}$ Nursing Department, Faculty of Nursing, Universitas Nahdlatul Ulama Surabaya, Jalan SMEA No.

57 Surabaya, East Java 60237

${ }^{3}$ Nursing Department, Faculty of Nursing, Universitas Airlangga, Jalan Dr. Ir. H. Soekarno, Mulyorejo, Kec. Mulyorejo, Surabaya, East Java 60115

*Corresponding author: siti.nurjanah-2021@fkp.unair.ac.id

\begin{abstract}
Acute Lymphoblastic Leukemia (ALL) is the most common childhood cancer, and ALL is the leading cause of death in children. Chronic diseases, one of which is cancer suffered by children, can provide varied responses to families. Caring for children with cancer requires a very long and complex process, so it requires good coordination between children, parents, families and the health team. The purpose of this literature review is to obtain in-depth information on the experiences of parents in caring for children with cancer. The method of writing this article is a literature review of 40 articles with the year 2019-2021 published from electronic database, namely CINAHL, Web of Science, SAGE and Proquest. The method of searching and selecting articles used The Center for Review and Dissemination and the Joanna Briggs Institute Guideline and PRISMA diagram. Checklist with selection criteria using the PICOS approach. The results of a literature review show that while caring for children with cancer, parents experience stress, anxiety about losing a child, uncertainty in child treatment, difficulties in caring for children and family responsibilities. Support in the form of psychosocial, material, and social support is needed for parents. The declining health condition of children is the biggest obstacle for parents, material needs are needed to support the care of children suffering from cancer, and there is hope from parents for their child's recovery.
\end{abstract}

Keywords: acute lymphoblastic leukemia, cancer, children, parent experiences

\section{INTRODUCTION}

Currently, cancer is a serious disease and threatens the health of children in the world. According to data from the World Health Organization (WHO), every year there are 6.25 million people with cancer in the world, of which $4 \%$ or 250 thousand are children. Cancer is a disease that can be suffered by anyone, regardless of age, whether children, adolescents or adults. The incidence of cancer in children in Indonesia has also increased, namely 100,000 children. Child cancer data in Jakarta from 19,000 cases to 14 million with a death rate of 8.2 million cases (Nahata et al., 2019).

Chronic disease in this case cancer suffered by children can give different responses to families and this is influenced by experience. The impact of cancer suffered by children can cause parents to experience a psychological response which is very important to study because it can have an influence on other family members and the psychology of the child himself. The values held by the family and the ethnic or cultural background that comes from the ancestors will affect the belief in a disease. Each case has a different problem, this can be influenced by NOTE: This preprint reports new research that has not been certified by peer review and should not be used to guide clinical practice. 
cultural, religious and ethnic backgrounds as well as the health management system that is not the same in every family (Lambert et al., 2021).

Every family with or without children with leukemia has problems that usually arise in the family, including financial problems, competition for attention between siblings, attention to children or other family members, and the ability to cope with important periods in the child's development. Families who have children with leukemia will cause a heavy burden for other family members. Parents will feel guilty and feel responsible for what happened to their children, or even parents hope to replace and bear the disease suffered by their children. Parents need help and support from all parties involved, both for the welfare of the parents themselves and for efforts to heal and care for their children. Some parents will feel stressed and there are many things that must be known in recognizing and understanding the experiences of parents caring for children with leukemia (Bouffet et al., 2020).

Psychological discomfort that parents often feel as caregivers of children suffering from blood cancer or leukemia are feelings of anxiety and depression by parents (56\%), guilt, fear, worry, sadness, depression will be felt for approximately 5 years and can be back to normal after a few years. The experience of parents in caring for children with cancer can be explored through qualitative studies. The qualitative method used in nursing is an approach that aims to obtain complete and specific, in-depth information and understand what parents are experiencing so that they can help and provide the support needed by patients and their families (SINAGA, 2017). Several factors contributed to treatment failure, namely economic factors, education level. Stress experienced by parents, lack of knowledge about side effects of treatment and how to deal with them and lack of experience in caring for children can also have an impact on parents' ability to care for children with cancer. Therefore, information related to the experience of caring for and the need for information based on the perceptions of parents is very important in the success of the goal of successful treatment and care for children with cancer (Erker et al., 2018).

\section{METHOD}

\section{Eligibillity criteria}

Determine the criteria with an article search strategy with the PICOS framework (Population, Intervention, Comparison, Outcome, Study type) which is also adjusted to the inclusion and exclusion criteria (table 1) below

Table 1. Inclusion and Exclusion criteria in PICOS

\begin{tabular}{lll}
\hline \multicolumn{1}{c}{ Criteria } & \multicolumn{1}{c}{ Inclusion } & \multicolumn{1}{c}{ Exclusion } \\
\hline Population & Child (age 1-17 years) & Teenager, Adult \\
\hline Intervention & Child nursing care & There is no criteria exclusion \\
\hline Comparison & There is no comparison & There is no criteria exclusion \\
\hline Outcome & $\begin{array}{l}\text { Family experiences in caring of } \\
\text { children with leukemia }\end{array}$ & $\begin{array}{l}\text { No family experiences in caring } \\
\text { of children with leukemia }\end{array}$ \\
\hline Study type & Qualitative study & Cross sectional study, mixed \\
& & method, quasi experimental \\
& & design, clinical trial or \\
& randomized controlled trial, \\
& Systematic or literature reviews
\end{tabular}

\section{Search strategy}

The literature search begins by determining the keywords to be used using Boolean operators (AND, OR NOT or AND NOT). The keywords in this literature review were adjusted according to the Medical Subject Heading (MeSH) namely "leukemia" OR "acute 
medRxiv preprint doi: https://doi.org/10.1101/2022.01.18.22269327; this version posted January 27, 2022. The copyright holder for this preprint (which was not certified by peer review) is the author/funder, who has granted medRxiv a license to display the preprint in perpetuity.

It is made available under a CC-BY-NC-ND 4.0 International license

lymphoblastic leukemia" AND "child" OR "children" AND "experience" OR "family experience" OR "parent experience". The databases used in the literature search were Scopus, CINAHL, Web of science, SAGE and Proquest, namely English articles for the last 5 years, 2016 - 2021, obtained 170 records, then filtered to remove duplicates, 153 records were obtained. The screening of records was determined by the eligibility criteria with the article search strategy with the PICOS framework which was also adjusted to the inclusion and exclusion criteria (table 1), obtained 81 records. A total of 14 full-text articles were assessed for eligibility, and only 8 articles matched eligibility in the qualitative study.

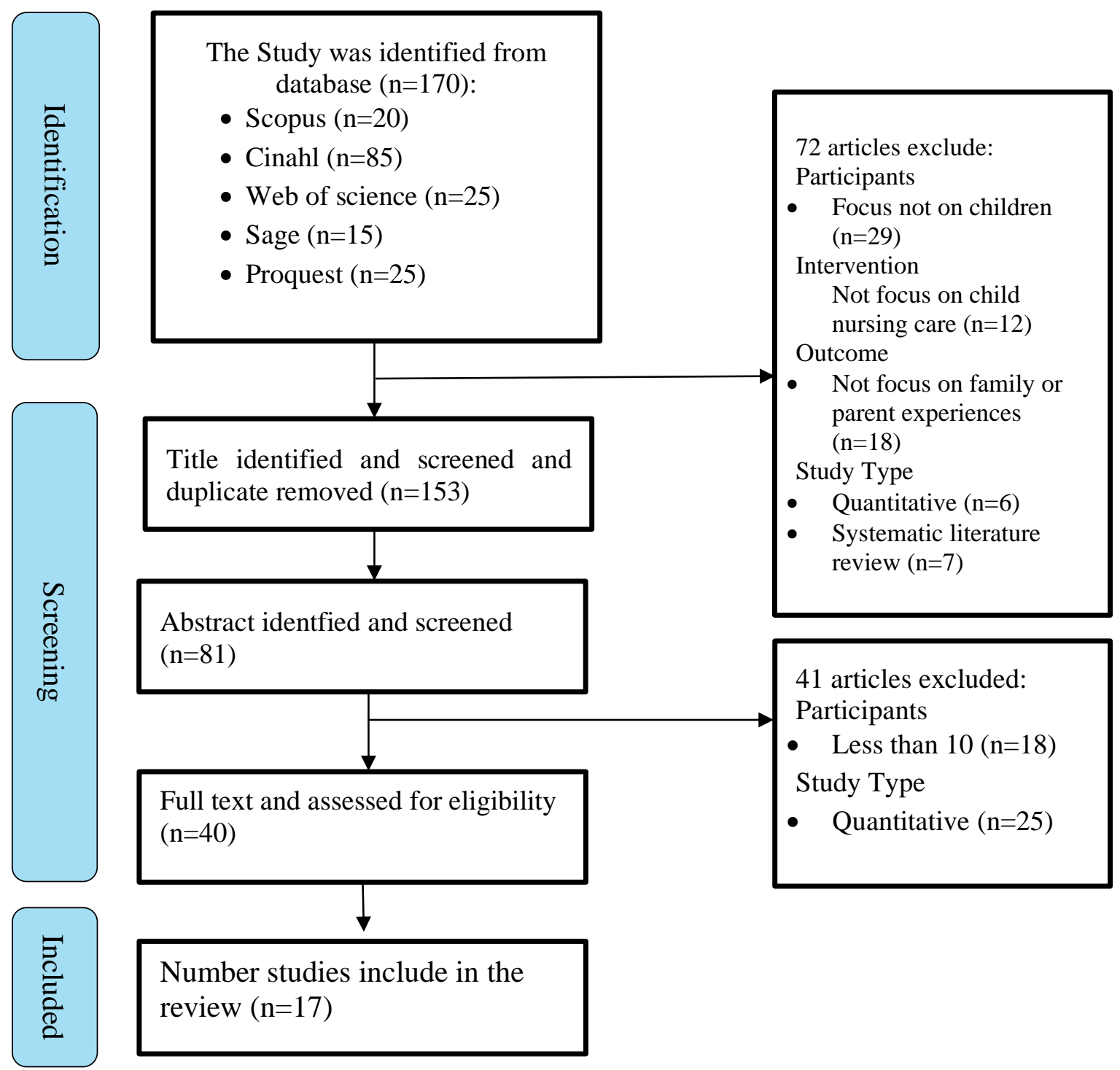

Figure 1. PRISMA Diagram of the Literature Search and Screening Process 


\section{RESULT}

Table 2 Literature search results

\begin{tabular}{|c|c|c|c|}
\hline No & Title, author, year & Method & Result \\
\hline 1 & $\begin{array}{l}\text { Early advice on managing } \\
\text { children with cancer during } \\
\text { the COVID-19 pandemic } \\
\text { and a call for sharing } \\
\text { experiences (Bouffet et al., } \\
\text { 2020) }\end{array}$ & $\begin{array}{l}\text { Design: qualitative } \\
\text { Sample: } 12 \text { parents } \\
\text { Variable: } \\
\text { experiences } \\
\text { Instrument: } \\
\text { interview sheet } \\
\text { Analysis: Explore } 3 \text { themes }\end{array}$ & $\begin{array}{l}\text { Revealing } 3 \text { main themes, } \\
\text { namely intrapersonal impact, } \\
\text { interpersonal relationship and } \\
\text { financial implications }\end{array}$ \\
\hline 2 & $\begin{array}{l}\text { Impact of pediatric cancer } \\
\text { on family relationships } \\
\text { (Erker et al., 2018) }\end{array}$ & $\begin{array}{l}\text { Design: qualitative } \\
\text { Sample: } 73 \text { parents } \\
\text { Variable: parents } \\
\text { experiences } \\
\text { Instrument: short form } \\
\text { Analysis: - }\end{array}$ & $\begin{array}{l}\text { Revealing that there is a sick } \\
\text { family member gives a sense of } \\
\text { stress, financial disturbances, } \\
\text { sometimes causing jealousy } \\
\text { attention }\end{array}$ \\
\hline 3 & 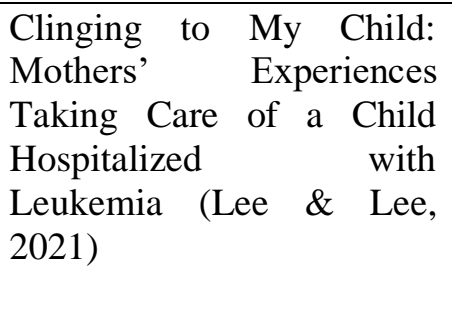 & $\begin{array}{l}\text { Design: qualitative } \\
\text { Sample: } 11 \text { parents } \\
\text { Variable: parents } \\
\text { experiences } \\
\text { Instrument: structured } \\
\text { interview sheet } \\
\text { Analysis: Explore } 5 \text { themes }\end{array}$ & $\begin{array}{l}\text { Identify five categories of } \\
\text { experiences including death } \\
\text { anxiety, } \\
\text { responsibilities as a mother, } \\
\text { feeling overwhelmed with life, } \\
\text { feeling pressured to be a good } \\
\text { mother, feeling burdened by life }\end{array}$ \\
\hline
\end{tabular}

\begin{tabular}{l}
\hline 4 Siblings' Experiences of \\
Everyday Life in a Family \\
Where One Child Is \\
Diagnosed With Blood \\
Cancer: A Qualitative \\
Study(Van Schoors, De \\
Paepe, et al., 2019)
\end{tabular}

$5 \quad$ A qualitative study of the costs experienced by caregivers of children being treated for cancer in New Delhi, India (Mardakis et al., 2019)
Design: qualitative

Sample: 10 siblings

Variable:

experience with leukemia

family

Instrument: $\quad$ Structured

interview sheet

Analysis: Verbatim

Design: qualitative

Sample: 25 parents

Variable: Experience about

the cost of children with

leukemia

Instrument: $\quad$ Structured

interview of 3 institutions in

India, using English and

Indian

Analysis:

Interview in verbatim

analysis

\begin{tabular}{ll}
\hline $6 \quad$ Parents' Experiences of \\
Having a Young Child With \\
Acuter Lymphoblastic \\
Leukemia in China (Liu et al., \\
2021)
\end{tabular}

Design: qualitative

Sample: 10 parents

Variable:

Parents'

experience of having a child

with leukemia
Overall, siblings experience continuity in many aspects, the family is an important support and source of communication, the family is a provider of warmth and affection, there are changes in the roles and responsibilities of each family member.

All participants described the direct and indirect and psychosocial costs associated with the care of their children. The main sources of direct costs are hospital admission, medicine, food and travel expenses. Indirect costs of maintenance management costs. This interferes with sleep, takes up work hours, interferes with time with other family members Five categories of themes: diagnosis of cancer as a terrible disaster, Like the sky is falling, fighting disease, telling how to recognize the diagnosis, hope of returning to normal life. Parents 


\begin{tabular}{|c|c|c|c|}
\hline & & $\begin{array}{l}\text { Instrument: In-depth face- } \\
\text { to-face interview } \\
\text { Analysis: Verbatim, In- } \\
\text { depth interview }\end{array}$ & $\begin{array}{l}\text { place their child's health as a top } \\
\text { priority, seek to manage } \\
\text { uncertainty about the prognosis } \\
\text { of their illness and cope with the } \\
\text { immense stress caused by the } \\
\text { child's suffering, financial } \\
\text { burden, stigma and family } \\
\text { support as reinforcement. }\end{array}$ \\
\hline 7 & $\begin{array}{l}\text { The parental experiences of } \\
\text { caring for children with } \\
\text { childhood cancers in } \\
\text { Singapore: a pilot focus } \\
\text { group study (Tan et al., } \\
\text { 2020) }\end{array}$ & $\begin{array}{l}\text { Design: qualitative } \\
\text { Sample: } 12 \text { children aged 5- } \\
7 \text { years } \\
\text { Variable: Child's } \\
\text { experience with leukemia } \\
\text { Instrument: Interview with } \\
\text { draw and tell technique } \\
\text { Analysis: inductive }\end{array}$ & $\begin{array}{l}\text { Four themes are defined. The } \\
\text { impact of treatment effects, } \\
\text { experiencing a changed } \\
\text { relationship, } \\
\text { gratitude, coping strategies. } \\
\text { Children appreciate the support } \\
\text { of other, children have their own } \\
\text { way of dealing with treatment } \\
\text { procedures. }\end{array}$ \\
\hline
\end{tabular}

\begin{tabular}{|c|c|c|c|}
\hline 8 & $\begin{array}{l}\text { Caring for a Child with } \\
\text { Cancer: Experiences } \text { of } \\
\text { Jordanian Mothers (Shattnawi } \\
\text { et al., 2021) }\end{array}$ & $\begin{array}{l}\text { Design: qualitative } \\
\text { Sample: 11 parents } \\
\text { Variable: } \quad \text { Parents' } \\
\text { experiences with children } \\
\text { with leukemia in Jordan } \\
\text { Instrument: } \quad \text { In-depth } \\
\text { interview } \\
\text { Analysis: - }\end{array}$ & $\begin{array}{l}\text { Emerging themes: emotional } \\
\text { response, fear of illness, } \\
\text { challenges in the treatment } \\
\text { process (financial, role } \\
\text { transition, feeling socially } \\
\text { isolated). Describe the } \\
\text { experiences of mothers in } \\
\text { Jordan caring for children with } \\
\text { cancer so that health care } \\
\text { providers can develop strategies } \\
\text { to provide adequate } \\
\text { psychological support }\end{array}$ \\
\hline 9 & $\begin{array}{l}\text { Returning to daily life: a } \\
\text { qualitative interview study on } \\
\text { parents of childhood cancer } \\
\text { survivors in Germany (Peikert } \\
\text { et al., 2020) }\end{array}$ & $\begin{array}{l}\text { Design: qualitative } \\
\text { Sample: } 31 \text { parents and } \\
\text { cancer survivors } \\
\text { Variable: The experience of } \\
\text { parents and children with } \\
\text { leukemia in Germany } \\
\text { Instrument: Structured } \\
\text { interview } \\
\text { Analysis: - }\end{array}$ & $\begin{array}{l}\text { During treatment, parents said } \\
\text { that } 70 \% \text { had difficulty in } \\
\text { managing work, family } \\
\text { responsibilities in caring for a } \\
\text { sick child, } 25 \% \text { spent time with } \\
\text { their partner, frequent disputes., }\end{array}$ \\
\hline 10 & $\begin{array}{l}\text { Patient and Parent Experiences } \\
\text { with Group Telerehabilitation } \\
\text { for Child Survivors of Acute } \\
\text { Lymphoblastic Leukemia } \\
\text { (Lambert et al., 2021) }\end{array}$ & $\begin{array}{l}\text { Design: qualitative } \\
\text { Sample: } 12 \text { parents and } \\
\text { children with cancer } \\
\text { Variable: The experience of } \\
\text { parents and children with } \\
\text { leukemia } \\
\text { Instrument: } \\
\text { interview } \\
\text { Analysis: - }\end{array}$ & $\begin{array}{l}\text { The overall theme identified } \\
\text { was the program's modality, } \\
\text { namely the approach of paired } \\
\text { groups between parents and } \\
\text { children, the telerehabilitation } \\
\text { system. Both parents and } \\
\text { patients expressed high } \\
\text { satisfaction with the program } \\
\text { and the benefits they felt }\end{array}$ \\
\hline 11 & $\begin{array}{l}\text { Meal planning values } \\
\text { impacted by the cancer } \\
\text { experience in families with } \\
\text { school-aged survivors-a } \\
\text { qualitative exploration and }\end{array}$ & $\begin{array}{l}\text { Design: qualitative } \\
\text { Sample: 11 parents } \\
\text { Variable: } \\
\text { experience }\end{array}$ & $\begin{array}{l}\text { Four main categories. Efforts } \\
\text { include time and difficulty, } \\
\text { budget, health, family } \\
\text { preferences. These values are } \\
\text { influenced by the experience of }\end{array}$ \\
\hline
\end{tabular}




\begin{tabular}{|c|c|c|c|}
\hline & $\begin{array}{l}\text { recommendations for } \\
\text { intervention development } \\
\text { (Raber et al., 2020) }\end{array}$ & $\begin{array}{l}\text { Instruments: Structured } \\
\text { interviews, video and audio } \\
\text { recordings } \\
\text { Analysis: - }\end{array}$ & $\begin{array}{l}\text { cancer at diagnosis, during } \\
\text { treatment and survival }\end{array}$ \\
\hline 12 & $\begin{array}{l}\text { Survivorship care plan } \\
\text { experiences among } \\
\text { childhood acute } \\
\text { lymphoblastic leukemia } \\
\text { patients and their families } \\
\text { (Pannier et al., 2019) }\end{array}$ & $\begin{array}{l}\text { Design: qualitative } \\
\text { Sample: } 13 \text { parents and } \\
\text { children } \\
\text { Variable: Experience of } \\
\text { parents and children } \\
\text { Instrument: Structured } \\
\text { interview, SCP format } \\
\text { Analysis: - }\end{array}$ & $\begin{array}{l}\text { Satisfaction with the } \\
\text { survivorship plan (SCP) is } \\
\text { generally high. Some parents } \\
\text { said that SCP should be given } \\
\text { immediately after treatment. } \\
\text { Having SCP can help them } \\
\text { make decisions about future } \\
\text { health care }\end{array}$ \\
\hline 13 & $\begin{array}{l}\text { Parental experiences and } \\
\text { coping strategies when } \\
\text { caring for a child receiving } \\
\text { paediatric palliative care: a } \\
\text { qualitative study (Verberne } \\
\text { et al., 2019) }\end{array}$ & 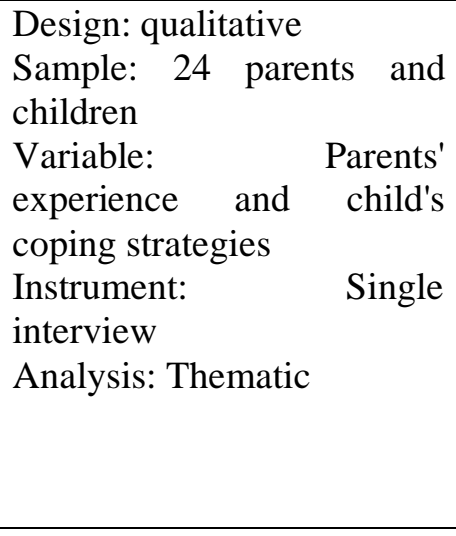 & $\begin{array}{l}\text { The parental experiences that } \\
\text { are conveyed and most } \\
\text { prominent are the anxiety of } \\
\text { losing a child, the confrontation } \\
\text { of sadness, maintaining a } \\
\text { meaningful relationship with the } \\
\text { child. Four related coping } \\
\text { strategies include: suppressing } \\
\text { emotions, seeking support, } \\
\text { taking control to manage the } \\
\text { parenting, and adapting to } \\
\text { ongoing changes. }\end{array}$ \\
\hline 14 & $\begin{array}{l}\text { Communication Priorities and } \\
\text { Experiences of Caregivers of } \\
\text { Children With Cancer in } \\
\text { Guatemala (Graetz et al., } \\
\text { 2021) }\end{array}$ & $\begin{array}{l}\text { Design: qualitative } \\
\text { Sample: } 65 \text { families } \\
\text { Variable: } \\
\begin{array}{l}\text { experience and } \\
\text { coping strategies } \\
\text { Instrument: }\end{array} \\
\begin{array}{l}\text { interview } \\
\text { Analysis: Thematic }\end{array} \\
\end{array}$ & $\begin{array}{l}\text { Having a family who suffers } \\
\text { from cancer or chronic disease } \\
\text { causes not being able to enjoy } \\
\text { life, stress, feeling physically } \\
\text { tired }\end{array}$ \\
\hline 15 & $\begin{array}{l}\text { Parents' experience of } \\
\text { caring children with cancer: } \\
\text { A qualitative study with } \\
\text { phenomenological } \\
\text { approach (Pishkuhi et al., } \\
\text { 2018) }\end{array}$ & $\begin{array}{l}\text { Design: qualitative } \\
\text { Sample: } 13 \text { parents } \\
\text { Variable: Parents' } \\
\text { experience of caring for } \\
\text { children with cancer } \\
\text { Instrument: In-depth } \\
\text { interview } \\
\text { Analysis: Thematic }\end{array}$ & $\begin{array}{l}\text { The extracted themes consist of } \\
\text { eight main subtitles which } \\
\text { include parents' anxiety about } \\
\text { the death of their children, the } \\
\text { inability of parents to answer } \\
\text { their children's questions, the } \\
\text { inability of parents to have } \\
\text { proper behavior when dealing } \\
\text { with angry children, parental } \\
\text { suffering from the side of the } \\
\text { child. treatment. impact on } \\
\text { children, economic, social, and } \\
\text { psychological burden on the } \\
\text { family, lack of time, } \\
\text { experiencing the impact of } \\
\text { spiritual support, and influence } \\
\text { on parental relationships }\end{array}$ \\
\hline 16 & $\begin{array}{l}\text { Experiences of mothers on } \\
\text { parenting children with } \\
\text { leukemia (Cornelio et al., } \\
2016)\end{array}$ & $\begin{array}{l}\text { Design: qualitative } \\
\text { Sample: } 1 \text { parent } \\
\text { Variable: Parents' } \\
\text { experience of caring for } \\
\text { children with cancer }\end{array}$ & $\begin{array}{l}\text { The themes revealed were } \\
\text { important moments in life, } \\
\text { experiences with a seriously ill } \\
\text { child, having to keep a distance } \\
\text { from relatives, overcoming }\end{array}$ \\
\hline
\end{tabular}




\begin{tabular}{|c|c|c|c|}
\hline & & $\begin{array}{l}\text { Instrument: In-depth } \\
\text { interview } \\
\text { Analysis: Thematic }\end{array}$ & $\begin{array}{l}\text { financial and social } \\
\text { commitments, responding to } \\
\text { challenges, experiencing faith as } \\
\text { a key to survival, health issues. } \\
\text { present and future, and } \\
\text { optimism }\end{array}$ \\
\hline 17 & $\begin{array}{l}\text { Marieke Van Schools1, MD; } \\
\text { Jan De Mol2, PhD; Natacha } \\
\text { Laeremans3, MD; Lesley L. } \\
\text { Verhofstadt4, PhD; Liesbet } \\
\text { Goubert4, PhD; Hanna Van } \\
\text { Parys5, PhD (2019) }\end{array}$ & $\begin{array}{l}\text { Design: qualitative } \\
\text { Sample: 1 parent } \\
\text { Variable: Parents' } \\
\text { experience of caring for } \\
\text { children with cancer } \\
\text { Instrument: Verbatim } \\
\text { transcript } \\
\text { Analysis: Thematic }\end{array}$ & $\begin{array}{l}\text { The results showed that siblings } \\
\text { overall experienced continuity } \\
\text { in many aspects of their family } \\
\text { life: they still viewed their } \\
\text { family as an important source of } \\
\text { support and } \\
\text { information/communication, as } \\
\text { warmth and affection and as a } \\
\text { safe harbor where family } \\
\text { members aim to protect each } \\
\text { other. }\end{array}$ \\
\hline
\end{tabular}

\section{DISCUSSION}

The results of research that explores the experiences of parents, children's experiences and family experiences in caring for children with cancer or leukemia convey that there is a sense of stress experienced by families, feelings of sadness, panic, disappointment and confusion over their child's condition (Lambert et al., 2021).

In addition, there were four themes that were obtained, namely emotional responses: 1) "I feel sad today to hear that my child is sick with leukemia, I don't know how I feel" (P1). "Yes, sadly, I can't believe it (Craig E, Ke Yan, Liyun Z, Kristin B, Katryn E, 2020). Because they don't feel any symptoms" (P2). "Yes, I feel sad (bowed down), how come my child is sick like this" (P3). 2) Attitude during treatment: "just go through the treatment process, following the treatment schedule that has been planned" (P1). "We have to put our trust and try to follow the treatment process, every day we have to drink juice and watch our food" (P2). "For now, it's starting to feel a bit relieved, my child has started to feel less pain in the joints and is not vomiting anymore" (P3). 3) Support obtained: "There is support from my family, that's what makes me enthusiastic and should not give up" (P1). "What kind of support is it, because I was only told to be patient, it's good to say it because I didn't experience it myself" (P2). Yes, there must be support, especially from my family and from people who share the same fate as me. And that is very helpful" (P3). 4) Illness Impact: "This is the first child, because we are sick like this, we have to postpone having a younger sibling. I'm afraid it won't be taken care of later" (P1). "His father went to prison, brother, because we are economically pressed to pay for the treatment process and other needs so 
we look for shortcuts to do evil" (P2). "Yes, the impact on me. Because I have no appetite and can't go anywhere. Every time there is a sense of anxiety and fear" (Chivukula et al., 2018).

Families, especially mothers, will face challenges in accepting and adjusting to children suffering from leukemia. In addition to adapting to the child's condition, the mother and family also struggle to be able to deal with pressure during the treatment process, the high costs and confusion in dealing with their child's future. So it takes support from various parties to provide motivation and psychological support for families with children with leukemia (Kyololo et al., 2019).

According to other research results through interviews to identify the experience of parents in caring for children with leukemia, there are eight main themes, namely 1) parental concerns about the child's death, 2) the inability of parents to answer children's questions, 3) the inability of parents to handle child aggression, 4 ) parental discomfort and suffering due to treatment complications, 5) economic, social, and psychological difficulties with the family, 6) lack of parental time, 7) lack of spiritual support, 8) influence on parental relationships (Pishkuhi et al., 2018).

Many parents express great frustration over their child's recovery, and some think that the disease causes death and express great concern. "At first, I didn't believe at all that my son had been diagnosed with cancer, but ever since he got worse, I've been constantly thinking about losing him, and I can't sleep from these thoughts and worries at night... I have repeatedly asked God to give me death, not him" (Pishkuhi et al., 2018), Several studies have shown that chemotherapy is the worst patient experience during the treatment period. These studies show that chemotherapy, as an aggressive and severe treatment causes unwanted problems such as decreased quality of life and impaired function of parents and children. Problems of pain, hair loss, fatigue, dyspnea, and anorexia are the most problematic experiences during the treatment period from a parent's point of view. Therefore, appropriate interventions are needed to reduce treatment complications (Pishkuhi et al., 2018).

Mothers reveal many adjustments and lifestyle changes have to live with children with leukemia. Mothers expressed concern over the fact that they had to live with a sick child with the uncertainty of the child's prognosis. Mother expressed her feelings as "Since she was sick, I have never attended anyone's invitations to family events and other social gatherings. I was bound by the fear that something might happen at home during my absence. That's why I won't go." (Cornelio et al., 2016). 
For most siblings, family is an important source of support both during treatment and pre-diagnosis. We are always there for each other. Because sometimes we really need each other. In addition, most siblings seem to feel a growing connection within the family. They have a feeling that, within their family, they can rely on one another, and that other family members are available to share their concerns, emotions and experiences (Van Schoors, De Mol, et al., 2019).

\section{CONCLUSION}

Mothers and families play a major role in caring for and caring for children with leukemia. Must continue to take the child for check-ups to the hospital or health service. In addition, mothers also need support from their families, the environment and health workers to support and improve the level of health of their children. Mothers and families play a major role in caring for and caring for children with leukemia. Must continue to take the child for check-ups to the hospital or health service. In addition, mothers also need support from their families, the environment and health workers to support and improve the health status of their children. The study concluded that chronic diseases such as childhood leukemia have a negative impact on both the child and the mother who is the primary caregiver. Children become the focus of care in the family which can affect the welfare of other siblings in the family. The greatest burden that mothers of children with childhood leukemia face are the financial burdens associated with treatment and follow-up.

\section{LIMITATION AND RECOMMENDATION}

The limitation in this review is the search for qualitative study literature that discusses family experiences in caring for children with leukemia. It is hoped that this literature review can be used as literature in providing nursing interventions to families, both in the form of health education, empowerment, and support.

\section{ACKNOWLEDGEMENT}

The authors would like to thank all the researchers whose articles were used for the discussion in this paper.

\section{CONFLICT OF INTEREST}

The authors declare that there is no conflict of interest in writing this literature review. 


\section{AUTHOR CONTRIBUTION}

SN participated in the analysis and further refinement of the theme; researching the literature, interpreting themes in the context of the literature and writing the first draft of the manuscript. YS participated in improving the literature review manuscript and improving the grammar used. MP participated in directing the author to write a literature review manuscript.

\section{REFFERENCES}

Bouffet, E., Challinor, J., Sullivan, M., Biondi, A., Rodriguez-Galindo, C., \& PritchardJones, K. (2020). Early advice on managing children with cancer during the COVID19 pandemic and a call for sharing experiences. Pediatric Blood and Cancer, 67(7), 15. https://doi.org/10.1002/pbc.28327

Chivukula, U., Kota, S., \& Nandinee, D. (2018). Burden experience of caregivers of acute lymphoblastic leukemia: Impact of coping and spirituality. Indian Journal of Palliative Care, 24(2), 189-195. https://doi.org/10.4103/IJPC.IJPC_209_17

Cornelio, S. J., Nayak, B. S., \& George, A. (2016). Experiences of mothers on parenting children with leukemia. Indian Journal of Palliative Care, 22(2), 168-172. https://doi.org/10.4103/0973-1075.179608

Craig E, Ke Yan, Liyun Z, Kristin B, Katryn E, J. P. (2020). The Lived Experiences of Mothers Who Are Parenting Children With Leukemia. Cancer Nursing, ARTICLES: ONLINE ONLY The Lived Experiences of Mothers Who Are Parenting Children With Leukemia.

Erker, C., Yan, K., Zhang, L., Bingen, K., Flynn, K. E., \& Panepinto, J. (2018). Impact of pediatric cancer on family relationships. Cancer Medicine, 7(5), 1680-1688. https://doi.org/10.1002/cam4.1393

Graetz, D. E., Rivas, S. E., Wang, H., Vedaraju, Y., Fuentes, A. L., Caceres-Serrano, A., Antillon-Klussmann, F., Devidas, M., Metzger, M. L., Rodriguez-Galindo, C., \& Mack, J. W. (2021). Communication Priorities and Experiences of Caregivers of Children With Cancer in Guatemala. JCO Global Oncology, 7, 1529-1536. https://doi.org/10.1200/go.21.00232

Kyololo, O. M., Stevens, B. J., \& Songok, J. (2019). Mothers' perceptions about pain in hospitalized newborn infants in Kenya. Journal of Pediatric Nursing, 47, 51-57. https://doi.org/10.1016/j.pedn.2019.04.015

Lambert, G., Alos, N., Bernier, P., Laverdière, C., Drummond, K., Dahan-Oliel, N., Lemay, M., Veilleux, L. N., \& Kairy, D. (2021). Patient and parent experiences with group telerehabilitation for child survivors of acute lymphoblastic leukemia. International Journal of Environmental Research and Public Health, 18(7). https://doi.org/10.3390/ijerph18073610

Lee, D., \& Lee, S. (2021). Clinging to My Child: Mothers' Experiences Taking Care of a Child Hospitalized with Leukemia. Clinical Nursing Research, 30(4), 415-422. https://doi.org/10.1177/1054773820957479

Liu, Q., Petrini, M. A., Luo, D., Yang, B. X., Yang, J., \& Haase, J. E. (2021). Parents' Experiences of Having a Young Child With Acute Lymphoblastic Leukemia in China. Journal of Pediatric Oncology Nursing, 38(2), 94-104. 
https://doi.org/10.1177/1043454220975463

Mardakis, S., Arora, R. S., Bakhshi, S., Arora, A., Anis, H., \& Tsimicalis, A. (2019). A qualitative study of the costs experienced by caregivers of children being treated for cancer in New Delhi, India. Cancer Reports, 2(3), 1-7. https://doi.org/10.1002/cnr2.1149

Nahata, L., Morgan, T. L., Lipak, K. G., Clark, O. E., Yeager, N. D., O’Brien, S. H., Whiteside, S., Audino, A., Quinn, G. P., \& Gerhardt, C. A. (2019). Perceptions of participating in family-centered fertility research among adolescent and young adult males newly diagnosed with cancer: A qualitative study. Pediatric Blood and Cancer, 66(11), 1-7. https://doi.org/10.1002/pbc.27966

Pannier, S. T., Mann, K., Warner, E. L., Rosen, S., Acharya, A., Hacking, C., Gerdy, C., Wright, J., Wu, Y. P., \& Kirchhoff, A. C. (2019). Survivorship care plan experiences among childhood acute lymphoblastic leukemia patients and their families. BMC Pediatrics, 19(1), 1-9. https://doi.org/10.1186/s12887-019-1464-0

Peikert, M. L., Inhestern, L., Krauth, K. A., Escherich, G., Rutkowski, S., Kandels, D., \& Bergelt, C. (2020). Returning to daily life: A qualitative interview study on parents of childhood cancer survivors in Germany. BMJ Open, 10(3), 1-8. https://doi.org/10.1136/bmjopen-2019-033730

Pishkuhi, M. A., Ahmadi, M., Shoraka, H., \& Chegeni, M. (2018). Parents' experience of caring children with cancer: A qualitative study with phenomenological approach. Journal of Comprehensive Pediatrics, 9(4). https://doi.org/10.5812/compreped.65545

Raber, M., Crawford, K., Baranowski, T., Sharma, S. V., Schick, V., Markham, C., Roth, M., Wakefield, C. E., \& Chandra, J. (2020). Meal planning values impacted by the cancer experience in families with school-aged survivors-a qualitative exploration and recommendations for intervention development. Supportive Care in Cancer, 28(3), 1305-1313. https://doi.org/10.1007/s00520-019-04928-5

Shattnawi, K. K., Okour, H., Alnatour, A., Al-Sheyab, N., Mrayan, L., \& Joseph, R. A. (2021). Caring for a Child with Cancer: Experiences of Jordanian Mothers. Clinical Nursing Research, 30(8), 1144-1152. https://doi.org/10.1177/10547738211002021

SINAGA, M. (2017). RISET KESEHATAN. manotar sinaga. https://books.google.co.id/books?id=8ZHeDwAAQBAJ

Tan, B. W. Z., Clarke, A., Teo, L. L., Tong, J. W. K., \& Chan, M. Y. (2020). The parental experiences of caring for children with childhood cancers in Singapore: a pilot focus group study. Proceedings of Singapore Healthcare, 29(3), 183-189. https://doi.org/10.1177/2010105820935915

Van Schoors, M., De Mol, J., Laeremans, N., Verhofstadt, L. L., Goubert, L., \& Van Parys, H. (2019). Siblings' Experiences of Everyday Life in a Family Where One Child Is Diagnosed With Blood Cancer: A Qualitative Study. Journal of Pediatric Oncology Nursing, 36(2), 131-142. https://doi.org/10.1177/1043454218818067

Van Schoors, M., De Paepe, A. L., Lemiere, J., Morez, A., Norga, K., Lambrecht, K., Goubert, L., \& Verhofstadt, L. L. (2019). Family Adjustment When Facing Pediatric Cancer: The Role of Parental Psychological Flexibility, Dyadic Coping, and Network Support. Frontiers in Psychology, 10(December), 1-12. https://doi.org/10.3389/fpsyg.2019.02740

Verberne, L. M., Kars, M. C., Schouten-van Meeteren, A. Y. N., van den Bergh, E. M. M., Bosman, D. K., Colenbrander, D. A., Grootenhuis, M. A., \& van Delden, J. J. M. (2019). Parental experiences and coping strategies when caring for a child receiving paediatric palliative care: a qualitative study. European Journal of Pediatrics, 178(7), 1075-1085. https://doi.org/10.1007/s00431-019-03393-w 


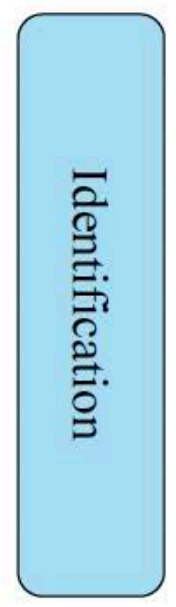

The Study was identified from database $(n=170)$ :

- Scopus $(\mathrm{n}=20)$

- Cinahl $(\mathrm{n}=85)$

- Web of science $(\mathrm{n}=25)$

- Sage $(n=15)$

- Proquest ( $\mathrm{n}=25)$
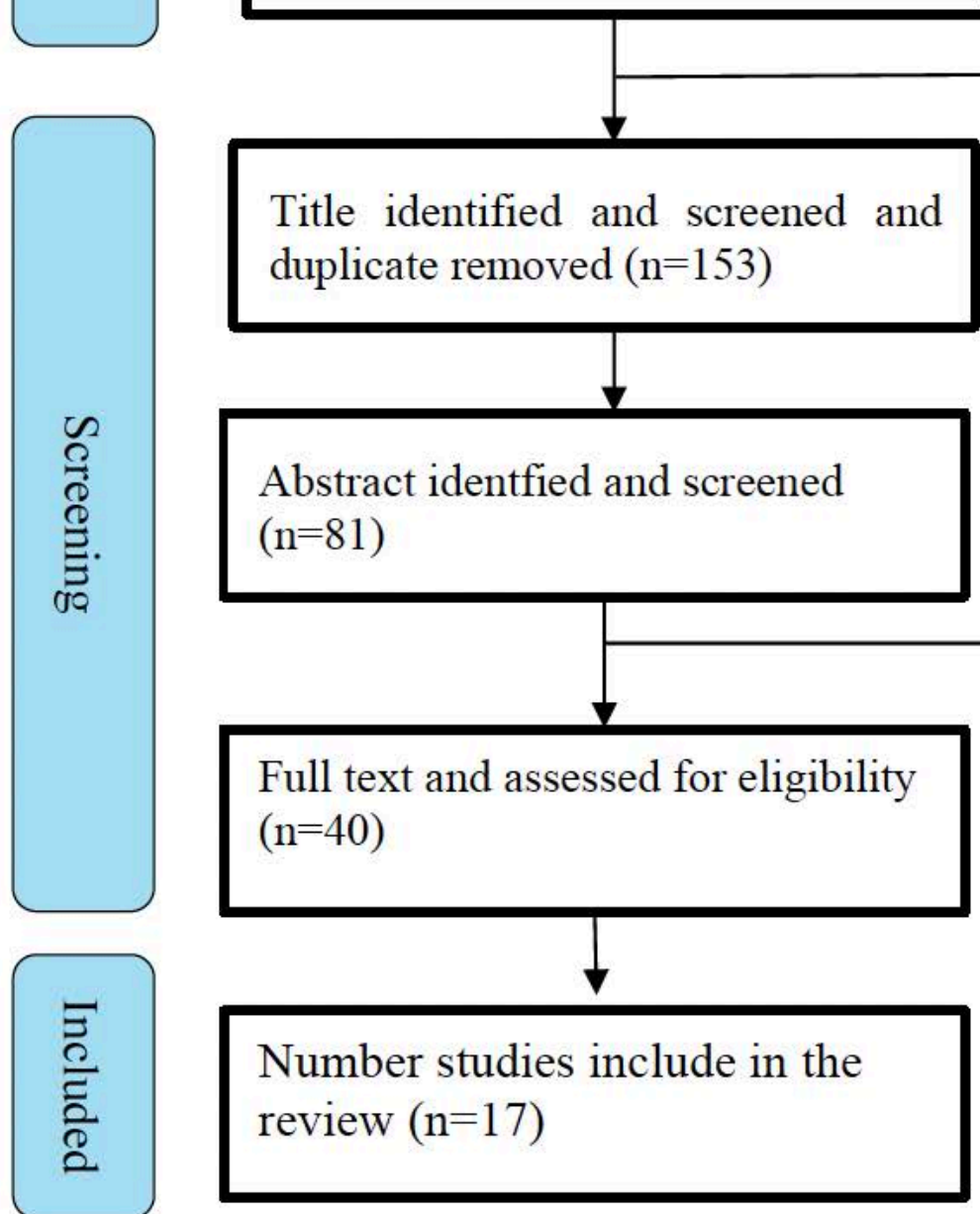

72 articles exclude:

Participants

- Focus not on children $(\mathrm{n}=29)$

Intervention

Not focus on child nursing care $(\mathrm{n}=12)$

Outcome

- Not focus on family or parent experiences $(\mathrm{n}=18)$

Study Type

- Quantitative $(\mathrm{n}=6)$

- Systematic literature review $(\mathrm{n}=7)$

41 articles excluded:

Participants

- Less than $10(\mathrm{n}=18)$

Study Type

- Quantitative $(\mathrm{n}=25)$ 